\begin{tabular}{ll}
\hline & $\begin{array}{l}\text { Kastamonu Eğitim Dergisi } \\
\text { Kastamonu Education Journal }\end{array}$ \\
$\begin{array}{l}\text { Ocak 2019 Cilt:27 Sayı:1 } \\
\text { kefdergi.kastamonu.edu.tr }\end{array}$ & Başuru Tarihi/Received: 26.12 .2017 \\
Kabul Tarihi/Accepted: 05.02 .2018 \\
Dol: $10.24106 /$ kefdergi.2503
\end{tabular}

\title{
Yansıtıcı Düşünme Etkinliklerinin Altıncı Sınıf Öğrencilerinin Matematik Tutumuna Etkisi ${ }^{1}$
}

\section{The Effect of Reflective Thinking Activities on Sixth Grade Students' Attitude towards Mathematics ${ }^{1}$}

\section{Öz}

\author{
Fatma ERDOĞAN², Sare ŞENGÜL ${ }^{3}$
}

Araştırmanın amacı, yansıtıcı düşünme etkinliklerinin altıncı sınıf öğrencilerinin matematik tutumu üzerindeki etkisini incelemektir. Araştırma, ön test-son test kontrol gruplu yarı deneysel model kapsamında düzenlenmiştir. Araştırmanın çalışma grubu 72 altıncı sınıf öğrencisinden oluşmaktadır. Dersler, deney grubunda yansıtıcı düşünme etkinlikleriyle işlenmiştir. Kontrol grubunda ise mevcut matematik dersi öğretim programına uygun bir matematik öğretimi gerçekleştirilmiştir. Veri analizinde bağımlı ve bağımsız örneklemler t-testi, ayrıca grupların son test puanları arasındaki farkı belirlemek için kovaryans analizi (ANCOVA) kullanılmıştır. Bulgulara göre, deneysel uygulamaların ardından, deney grubundaki öğrencilerin matematik dersine yönelik tutumlarının kontrol grubundaki öğrencilere kıyasla anlamlı seviyede yüksek olduğu saptanmıştır. Araştırmada ulaşılan bulgulara dayanarak, yansıtıcı düşünme etkinliklerinin öğrencilerim matematik tutumları üzerinde pozitif etkisinin olduğu söylenebilir. Elde edilen bulgular göz önüne alınarak, araştırma sonunda, yansıtıcı düşünme etkinlikleri ile araştırma yapacak araştırmacılara yönelik öneriler sunulmuştur.

Anahtar Kelimeler: Yansıtıcı düşünme, matematik tutumu, matematik öğretimi, ortaokul

\section{Abstract}

The aim of this research was to examine the effect of reflective thinking activities on sixth grade students' attitude towards mathematics. The research has been arranged as the pre- and post-test control group quasi-experimental design. The research participants were composed of 72 sixth grade students. Reflective thinking activities were used in the experimental group. In the control group, mathematics teaching was carried out in accordance with the curriculum of the mathematics course. Dependent and independent samples t-test were used in data analysis, and covariance analysis (ANCOVA) was applied to determine the difference regarding post-tests scores of the groups. According to the results of the data analysis, at the end of the interventions, it seemed that the attitude towards mathematics of the experimental group students were significantly higher than the attitudes of the control group students. Based upon the findings of this study, it can be concluded that reflective thinking activities have a positive effect on students' attitude towards mathematics. Considering the findings, the researchers have offered suggestions for those who are to perform any other research on reflective thinking activities.

Keywords: Reflective thinking, attitude towards mathematics, mathematics teaching, middle school

1. Bu çalışma, 26-28 Ekim 2017 tarihlerinde Kahramanmaraş Sütçü İmam Üniversitesi'nde gerçekleştirilen 3. Uluslararası Sosyal Bilimler Sempozyumu'nda sözlü bildiri olarak sunulmuştur.

2. Fırat Üniversitesi, Elazığ, Türkiye; https://orcid.org/0000-0002-4498-8634

3. Marmara Üniversitesi, İstanbul, Türkiye; https://orcid.org/0000-0002-1069-9084

Atıf / Citation: Erdoğan, F., \& Şengül, S. (2019). Yansıtıcı düşünme etkinliklerinin altıncı sınıf öğrencilerinin matematik tutumuna etkisi. Kastamonu Education Journal, 27(1), 247-260. doi:10.24106/kefdergi.2503 


\section{Extended Summary}

\section{Introduction}

The aim of the present study was to examine the effect of reflective thinking activities on attitude towards mathematics of sixth grade students. It was revealed that the students' attitude towards mathematics would affect their performance considering the affective processes was the important part of learning (Samuelsson and Granström, 2007). In this respect, it can be said that the examination of the effect on the attitude towards mathematics of the applied strategies and materials to enhance the reflective thinking skills in the mathematics course will fill an important gap in the field. When reflective thinking is considered to be a high-level thinking skill (Mahnaz, 1997), the application of the activities for improving this skill and the examination of the results are seen meaningful and important in terms of mathematics education.

\section{Method}

In this research, a quantitative research approach was implemented and a quasi-experimental design with pre-and posttest control group was applied. Course processing process was carried out with reflective thinking activities in the experimental group $(n=37)$, while the normal process was resumed in the control group $(n=35)$. As a data collection tool, Mathematical Attitude Scale (MAS) developed by Nazlıçiçek and Erktin (2002) was used in the present study.

During the material preparation process, learning journal, two-column learning logs, reflective dialogue form, error evaluation form, prompting card materials were designed in the research. Writing, learning journal, learning logs, reflective dialogue, self-assesment, questioning, thinking aloud strategies were used the reflective thinking strategies among from strategies for developing reflective thinking skills were used in this conducted research. Analyzes were conducted with "the independent group t-test" and "the dependent group t-test". Covariance analysis (ANCOVA), with pretests as covariate, was used to determine the significance of the different between the groups' arithmetic means.

Findings

The results of the independent group t-test conducted on the MAS pre-test scores of the study groups showed no statistically significant difference in terms of the attitude towards mathematics $\left[t_{(70)}=-.34, p>.05\right]$. A statistically significant difference was found with regard to the research findings in the result of the dependent group t-test analysis applied to the test group MAS pre- and post-test scores of the experimental group $\left[\mathrm{t}_{(36)}=-4.51, \mathrm{p}<.05\right]$. It has been determined that there was a difference in favor of the post-test. Although, no statistically significant difference was found according to the dependent group $t$-test results applied to the control group's MAS pre- and post-test scores $\left[t_{(34)}=-.89, p>.05\right]$. At the same time, when pre-test scores were under control, a statistically significant difference was determined according to the ANCOVA results among the MAS post-test scores of the groups $\left[F_{(1,69)}=11.37, p<.05\right]$. This difference is considered to be in favor of the experimental group.

\section{Discussion and Conclusion}

In the light of the findings above, there was a statistically significant difference between the MAS pre and post test scores of the experimental group students after experimental applications in the group comparisons. The significant difference obtained was found to be in favor of the post-test. No statistically significant difference was found to be between the MAS pre and post test scores of the control group. As a result of the research, a statistically significant difference was found between the MAS post-test scores of the experimental and control groups according to the results of intergroup comparison after the experimental applications in the experimental group. This significant difference appears to be in favor of the experimental group. Based upon these findings, it can be concluded that reflective thinking activities have a positive effect on students' attitude towards mathematics. When considered the important role of "activities" in the development of reflective thinking skills (Taber, 2008), it can be argued that the activities applied in the research, activating and reflective events contribute to the development of the attitude towards mathematics of the students. Research findings that revealed the reflective activities have a positive effect on student attitudes towards the course support these results (Baş and Beyhan, 2012; Demirel, Derman, and Karagedik, 2015; Tok, 2008; Grossman, 2009; Moon, 2006; Phan, 2009; Uygun and Çetin, 2014; Wilson and Jan, 1993).

Strategies such as writing, learning journal and learning logs applied in the research reflect the feelings of the students as well as learning processes. So, it can be said that these strategies have positive effects on improving the attitude towards mathematics of the students. Previous studies carried out in this area supports this argument (Burton, 2009; Can and Altuntaş, 2016; Farrah, 2012; Graham, 2003; Inoue ve Buczynski, 2011; Walker, 2006).

In the present study, reflective thinking strategies have been applied in a complementary manner each other. It is also thought that the using of structured materials facilitates the reflection of students. In future researches, the advantages and disadvantages can be discussed by comparing different reflective thinking strategies. It was aimed that students have high-level thinking skills in the mathematics curriculum developed according to the constructivist approach (Ministry of National Education, 2013). However, it has been observed that strategies, activities and materials for improving these skills were not adequately included. It would be efficacious for the students to have materials and activities to develop reflective thinking skills during program development stages. It is thought that the integration of strategies such as reflective dialogue with mathematics course content will contribute to the structuring of the program. In addition to all these, Wilson and Jan (1993) emphasized as priority that teachers should have reflective thinking skills. So, it is recommended that teachers and prospective teachers who are practitioners of the events for the development of reflective thinking skills of the students should be trained in the field of reflective thinking before and during the service. 


\section{Giriş}

Öğrencilerin hayat boyu öğrenme sürecinde önemli bir rolü olan yansıttcı düşünme, yaşam boyunca nasıl hareket edebileceğini düşünmenin bir yolu olarak ifade edilebilir (Grossman ve Williston, 2001). Dewey'e göre (1993) yansıttcı düşünme kişinin, sonuçtan çok sürece odaklanmasını gerektiren, bilgiyi etkin, tutarlı ve dikkatli bir şekilde düşünmesidir. Schön (1987) yansıtıcı düşünmeyi, öğrencinin bir konuyu veya problem durumunu açıklarken kendi düşünce, tutum, bilgi birikimi ve yetenekleriyle yoğurarak ortaya koyması şeklinde tanımlamıştır.

Alan yazında, yansıttcı düşünmenin matematik eğitimi açısından önem arz ettiği vurgulanmaktadır (Garcia, Sanchez ve Escudero, 2007; Kramarski, Weiss ve Sharon, 2013). Matematik öğrenme süreci; kavramlar arası ilişkilendirme, strateji seçme ve yansıtma öğelerini içermektedir (Kramarski vd., 2013). Yansıtıcı düşünme ve matematik eğitimi kapsamında yapılan araştırmalarda, yansıttcı düşünmenin matematikte anlamlı öğrenmeyi desteklediği ortaya konulmuştur (Inoue ve Buczynski, 2011; McNaught, 2010). Ayrıca, problem çözme bağlamında ele alındığında, yansıtıcı düşünme problem çözme süreci veya içerik hakkındaki sayılttların eleştirilmesini içerir (Mezirow, 1991). Öğrenciler yansıtmalar yoluyla çözümlerini ve problem çözme sürecini çeşitli açılardan ele alır ve eleştirirler. Dolayısıyla, yansıtıcı düşünme öğrencilerin problem çözme süreçlerini değerlendirmelerinde önemli rol oynar (Kramarski vd., 2013). Yansıttcı düşünmenin bir problem durumu algılandığında aktifleştiği düşünüldüğünde, öğrenci yansıtmaları problem çözme aşamalarında etkin bir şekilde gözlenebilir (Kızılkaya ve Aşkar, 2009). Bu bağlamda, yansıtıcı düşünme problem çözmeyi kapsamaktadır (Epstein, 2003). Bu bilgiler doğrultusunda, yansıtıcı düşünme becerisinin matematik eğitimi açısından önemli bir beceri olduğu söylenebilir.

Öğretimde yapılandırmacı yaklaşımı temel alan bir sorgulama durumu olan yansıtıcı düşünme ile birey sorgulama durumlarıyla birlikte yaşantılarını tekrar yapılandırma firsatı bulur (Mahnaz, 1997). Yapılandırmacı yaklaşıma göre yenilenen matematik dersi öğretim programı (Milli Eğitim Bakanlığı [MEB], 2013) öğrencileri aktif kattlımcı olarak ele almaktadır. Program, öğrencilerin sorgulama yapmalarına, iletişim kurmalarına, eleştirel düşünmelerine, neden ve niçinleri açıklamalarına, fikirlerini rahatlıkla paylaşabilmelerine imkan sağlayan sınıf ortamlarının oluşturulmasını vurgulamaktadır. Eleştirel düşünme ile yansıtıcı düşünme iç içe geçmiştir (Choy ve Oo, 2012; Incikabi, Tuna ve Biber, 2013). Bu bağlamda, yansıtıcı düşünmenin programın hedeflerinden biri olan eleştirel düşünme becerisinin harekete geçirilmesinde önemli rol oynadığı söylenebilir (King, Goodson ve Rohani, 2013). ilgili alan yazın göz önüne alındığında araştırma sonuçları, yansıtıcı düşünme becerisine sahip öğrencilerin deneyimlerinden yola çıkarak yeni öğrenmeler gerçekleştirdiklerini (Lindh ve Thorgren, 2016), öz-değerlendirme becerilerinin (Kramarski vd., 2013) ve eleştirel düşünme becerilerinin (Aryani, Rais ve Wirawan, 2017) yüksek seviyede olduğunu göstermektedir.

Alan yazın incelendiğinde, yansıtıcı düşünme becerisinin geliştirilebilir bir süreç olduğu belirtilmektedir (Taggart ve Wilson, 2005). Ancak, yansıtmanın zor bir süreç olduğu (Grossman, 2009) ve yansıtıcı düşünme becerisini geliştirme konusunda destek almayan öğrencilerin zorlanacakları vurgulanmaktadır (Lin, Hmelo, Kinzer ve Secules, 1999). Dolayısıyla, yansıtıcı düşünme kendiliğinden gelişen bir özellik olmaktan ziyade bireyin aktif bir öğrenme etkinliği içerisinde olmasını gerektirir (King vd., 2013). Bu doğrultuda, öğrenme ortamlarında öğrencilerin yansıtıcı düşünme becerilerini geliştirmek amacıyla destekleyici stratejilere yer verilmesi önemli görülmektedir (Moon, 2006; Taggart ve Wilson, 2005; Wilson ve Jan,1993).

Yansıtıcı düşünme becerisinin geliştirilmesinde kullanılan stratejilerden biri "yazma"dır. Yazma "kağıt üzerinde sesli düşünme" şeklinde ifade edilebilir (Pugalee, 2004). Araştırmalarda, yazma stratejisinin matematik öğretiminde önemli olduğu vurgulanmaktadır (Inoue ve Buczynski, 2011; Pugalee, 2004) Yazma stratejisiyle öğrenciler matematiksel içerik ve süreç hakkındaki düşüncelerini yansıttrlar (Inoue ve Buczynski, 2011). Ayrıca, yazma stratejisi öğretim ortamlarında yansıtmayı desteklemenin yanında öğrencilerin hoşlandığı bir aktivitedir (Burton, 2009). Yansıtıcı düşünme becerisini geliştirme stratejilerinden bir diğeri “öğrenme yazıları”dır. Öğrenme yazılarını kullanan öğrenciler öğrenme deneyimlerini, kişisel tepkilerini, öğrenme içeriğine yönelik bilgilerini ve yorumlarını yansıtma firsat bulurlar (Moon, 2010; Wilson ve Jan, 1993). Öğrenme yazılarında öğrenci bir sayfada bulunan kolonların bir tarafina etkinlik sonucu ulaştiğı bilgileri ve problem oluşturan sorunları; kolonun diğer tarafina öğretim etkinliğiyle ilgili durum değerlendirmesini yansıtan notları yazar (Wilson ve Jan, 1993).

Alan yazın incelendiğinde, yansıtıcı düşünme becerisini geliştirme sürecinde "günlük"lerin, sıklıkla kullanılan stratejilerden biri olduğu dikkat çekmektedir (Moon, 2006; Wilson ve Jan, 1993). Öğrenme günlükleri, öğrencilerin öğrenme süreciyle ilgili bilgilerini, şüphelerini, duygularını kendi cümleleriyle ifade ettikleri günlüklerdir (Wilson ve Jan, 1993). Öğrenciler, yansıtıcı günlükleri derste yaşadıkları ilginç deneyimlerle ilgili yazma, hayal gücünde tasarladıklarını kağıda dökme, eski ve yeni bilgilerini ilişkilendirme gibi birçok farklı amaçla kullanabilirler (Farrah, 2012; Gorlewski ve Greene, 
2011). Yansıtıcı düşünmenin ele alındığı araştırmalarda kullanılan bir diğer strateji "yansıtıcı diyalog"tur (Kramarski ve Kohen, 2017). Diyalog, tartş̧ılan konu üzerinde uzlaşma için uygun zemin yaratır, dönüt ve yansıtma için firsat sunar (Hinett, 2002). Yansıttcı diyalog, içsel ve bir başkasıyla olmak üzere iki şekilde sınıflanabilir. Başkasıyla gerçekleştirilen diyaloglarda öğrenciler; öğrendiklerini gözden geçirerek geliştirme amacıyla, önceden öğrendiği bilgileri sorgulayarak dönüştürme amacıyla ve öğrenme sürecini anlamak amacıyla yansıtma yapar (Brockbank ve McGill, 2006). Yansıtıcı düşünme becerisinin geliştirilmesinde kullanılan bir diğer strateji olan "sesli düşünme" ise bireyin düşünme gerektiren bir görevle meşgul olduğunda, düşünme süreçlerini yansıtmasıdır (Hartman, 2001; Taggart ve Wilson, 2005). Bireyin zihinsel süreçlerini değerlendirmesinin bir yolu da sesli düşünmedir (Pugalee, 2004).

Yansıtıcı düşünme becerisinin geliştirilmesinde önemli bir kavram olan "kendini değerlendirme" stratejisi ile öğrencilerin problem çözme performanslarını izlemeleri ve değerlendirmeleri sağlanabilir (Schoenfeld, 1985; Wilson ve Jan, 1993). Ayrıca, yansıticı düşünmenin geliştirilmesinde yönlendiriciler aracıllğıyla "sorgulama" stratejisini uygulayan araştrmalar mevcuttur (Davis, 2003; Ifenthaler, 2012; Kramarski ve Kohen, 2017; Kramarski vd., 2013). Yansıticı yönlendiriciler, sorgulama ifadeleri gibi dışsal uyarıcılardır (Kramarski ve Kohen, 2017). Yansıtıcı sorgulamalar aracılığıyla öğrencilerin öğrenmelerini planlayıp izlemeleri ve öz-açıklama yapmaları sağlanabilir (Davis, 2003; Ifenthaler, 2012).

Alan yazın incelendiğinde, yurt dışında öğrenim gören öğrencilerin yansıttcı düşünme becerilerini geliştirmek amacıyla farklı stratejilerin ve materyallerin uygulandığı araştrrmalar görülmektedir (Choy ve Oo, 2012; Farrah, 2012; Grossman, 2009; Grossman ve Williston, 2001; Inoue ve Buczynski, 2011; Kramarski vd., 2013; McNaught, 2010). Ancak, Türkiye'de yansıtıcı düşünme ve matematik öğretimi bağlamında gerçekleştirilen araştırmaların oldukça sınırlı sayıda olduğu görülmüştür. Baki, Güç ve Özmen (2012) matematik öğretmeni adaylarının problem çözme temelli bir öğrenme ortamında, problem çözmeye yönelik yansıtıcı düşünme becerilerini belirlemişlerdir. Yansıtıcı düşünme beceri düzeyini inceleyen araştırmalar ele alındığında ise, matematik öğretmenlerinin veya öğretmen adaylarının (Kandemir, 2015); öğrencilerin (Baş ve Kıvılcım, 2013; Demirel, Derman ve Karagedik, 2015; Saygılı ve Atahan, 2014; Şen, 2013) bazı değişkenlere göre yansıtıcı düşünme düzeylerinin incelendiği görülmüştür. Öğrencilerin yansıtıcı düşünme becerilerini geliştirmeye yönelik bir çalışma gerçekleştiren Kızılkaya (2009) araştırmasında, web tabanlı öğrenme ortamında yansıtıcı düşünme becerisinin problem çözmenin anlamlı bir yordayıcısı olduğunu belirlemiştir. Türkiye'de yansıtıcı düşünme becerisini konu edinen çalışmaların son yıllarda yapıldığı ve sayıca az olması dikkat çekmektedir.

Matematik eğitiminde hem bilişsel hem de duyuşsal süreçler öğrenmenin önemli bileşenleri olarak ele alınmaktadır (Caine ve Caine, 1991). Duyuşsal özelliklerden biri olan matematik tutumu, matematiği sevme veya sevmeme, matematiksel aktivitelerle uğraşma veya kaçınma eğilimi, matematikte iyi veya kötü olma inancı, matematiksel etkinliklerle uğraşma veya kaçma eğilimi ve matematiğin yararlı veya yararsız olduğuna yönelik inanç olarak tanımlanmaktadır (Neale, 1969). Matematik derslerinde öğrenci davranışları tutumlardan büyük ölçüde etkilenir. Örneğin, matematik dersinde etkinliklere aktif katılma veya dersten kaçınma matematik dersine yönelik negatif tutumla ilişkilidir (Mayes, Chase ve Walker, 2008). Alan yazın incelendiğinde araştırma bulguları, matematik başarısı ve tutum arasında pozitif iliş̧i olduğunu ortaya koymaktadır (Muzzatti ve Agnoli, 2007; Pimta, Tayruakham ve Nuangchalerm, 2009; Samuelsson ve Granström, 2007). Pimta vd. (2009) öğrencilerin problem çözme becerilerini doğrudan etkileyen faktörlerden birinin matematiğe yönelik tutum olduğunu belirtmişlerdir.

Matematik tutumu tek bir faktörle açıklanamaz. Matematik tutumunu etkileyen faktörler, öğrenci faktörleri (öz yeterlik, motivasyon), sosyal faktörler (anne-babanın eğitim durumu), okul ve öğretmenle ilgili faktörler (öğretmenin alan bilgisi, öğrenme ortamı) olarak sınıflanabilir (Mohamed ve Waheed, 2011). Araştırmalar, sosyal yönden destekleyici öğrenme ortamlarının (iletişim, işbirliği) öğrencilerin matematiğe yönelik pozitif tutum geliştirmelerine (Fraser ve Kahle, 2007; Mata, Monteiro ve Peixoto, 2012), sosyal yönden destekleyici olmayan sınıf ikliminin ise matematiğe yönelik olumsuz tutum geliştirmelerine neden olduğunu ortaya koymaktadır (Samuelsson ve Granström, 2007).

McLeod (1992) matematik eğitiminde öğrencilerin matematiğe yönelik niçin olumlu veya olumsuz tutum geliştirdiklerini anlamanın önemli olduğunu belirtmiştir. Ayrıca, öğrencilerin matematik tutumlarının pozitif yönde gelişmesi için öğretmenlerin öğrencilere nasıl yardımcı olacaklarının belirlenmesi gereklidir. Alan yazında, öğrencilerin matematik tutumlarının olumlu yönde geliştirilebileceğini ortaya koyan araştırmalar mevcuttur (Hodges ve Kim, 2013; Tichenor ve Plavchan, 2010). Bu araştırmalarda, öğrenme ortamlarının öğrenciyi aktif kılacak ve sosyal etkileşim sağlayacak şekilde düzenlenmesinin matematik tutumunu geliştirmede etkili olduğu ifade edilmiştir.

Son yıllarda, öğrencinin öğrenme sürecinde aktif olmasını gerekli kılan yansıtıcı düşünmenin, duyuşsal beceriler üzerindeki etkisini incelemeye yönelik çalışmalar yapılmaktadır (Farrah, 2012; Grossman, 2009; Inoue ve Buczynski, 2011; Moon, 2006; Walker, 2006). Türkiye'de yapılan çalışmalar incelendiğinde, yansıttcı düşünme etkinliklerinin İngilizce (Baş 
ve Beyhan, 2012), fen bilgisi (Tok, 2008) ve sosyal bilgiler (Uygun ve Çetin, 2014) derslerine yönelik öğrenci tutumları üzerinde olumlu etkisi olduğu ortaya konulmuştur. Matematik eğitimi alanında, Demirel vd. (2015) araştırmalarında yansıtıcı düşünme becerisi ile tutum arasında orta derecede pozitif yönlü bir ilişki olduğunu belirtmişlerdir.

Yansıtıcı düşünme etkinliklerinin öğrencilerin matematik tutumları üzerindeki etkisini inceleyen araşttrmaların sınırlı sayıda olduğu görülmektedir. Ayrıca, yansıtıcı düşünme becerisini geliştirmeye yönelik farklı stratejilerin kullanımının betimlendiği ve stratejilerin uygulanması sürecinde kullanılan materyallerin ayrıntılı sunulduğu bir çalışmaya rastlanamamıştr. Matematik dersinde yansıtıcı düşünme becerisini geliştirmeye yönelik uygulanan strateji ve materyallerin matematik tutumu üzerindeki etkisinin incelenmesinin alan yazındaki önemli bir boşluğu dolduracağı söylenebilir. Öğrenme ortamlarının ve öğrencilerin yaşadıkları deneyimlerin matematik tutumu üzerinde etkili olduğu göz önüne alınarak, yansıtıcı düşünme becerisini geliştirmeye yönelik etkinliklerin uygulanıp, sonuçların irdelenmesi matematik eğitimi açısından anlamlı ve önemli görülmektedir. Bu bağlamda, araştırmanın amacı, yansıtıcı düşünme etkinliklerinin altıncı sınıf öğrencilerinin matematik tutumuna etkisini incelemektir.

\section{Yöntem}

\section{Araştırmanın Modeli}

Araştırmada nicel araştırma yaklaşımı benimsenmiş; ön test-son test kontrol gruplu yarı deneysel model uygulanmıştır. Yarı deneysel model kullanılarak tasarlanan çalışmalar, grupların yapay şekilde oluşturulmasının güçlüğünden dolayı, grupların rastgele seçimini gerektirir. Araştırmacı, normal koşullarında bulunan gruplardan birini rastgele şekilde deney, diğer grubu ise kontrol grubu olacak şekilde belirler. Seçilen gruplara ön testler uygulanır. Sadece deney grubunda deneysel etkinlikler gerçekleştirilir ve ardından son testler gruplara uygulanarak farklılıklar irdelenir (Creswell, 2013).

\section{Çalışma Grubu}

Araştırma, 2016-2017 eğitim-öğretim yılında Doğu Anadolu Bölgesinde bulunan bir ortaokulun altıncı sınıflarında öğrenim gören toplam 72 öğrenci ile yürütülmüştür. Deney ve kontrol gruplarının belirlenmesinde rastlantısal yöntem benimsenmiştir. Ders işleme süreci, deney grubunda $(n=37)$ yansıtıcı düşünme etkinlikleri ile yürütülmüş, kontrol grubunda $(n=35)$ ise mevcut matematik dersi öğretim programına uygun bir matematik öğretimi gerçekleştirilmiştir.

Deney grubunda yer alan öğrencilerin 22'si kız (\%59.5), 15'i erkek (\%40.5); kontrol grubundaki öğrencilerin ise 20'si kız (\%57), 15'i erkektir (\%43). Her iki gruptaki kız öğrenci sayıları erkek öğrencilere kıyasla daha fazladır. Ayrıca, iki çalışma grubunda bulunan öğrenci sayılarının birbirine yakın değerde olduğu ifade edilebilir. Deney ve kontrol gruplarındaki öğrencilerin sosyo-ekonomik düzeylerinin benzer yapıda olması araştırmanın geçerliliği bakımından önemlidir (Creswell, 2013). Bu durum dikkate alınarak, çalışma grupları aynı devlet okulunda öğrenim gören öğrencilerden seçilmiştir.

\section{Veri Toplama Aracı}

Araştırmada, Nazlıçiçek ve Erktin (2002) tarafindan geliştirilen Matematik Tutum Ölçeği (MTÖ) kullanılmıştr. Ölçek, algılanan matematik başarı düzeyi, matematiğin yararları ve matematik dersine olan ilgi olmak üzere üç alt boyuttan, olumlu ve olumsuz ifadeler içeren 20 maddeden oluşmaktadır. Güvenirlik çalışmaları kapsamında ölçeğin iç tutarlıık katsayısı " $\alpha=.84$ " olarak hesaplanmıştr. Ölçeğin alt boyutları ele alındığında ise, matematikte algılanan başarı düzeyi, matematiğin yararları ve matematik dersine olan ilgi alt boyutları için güvenirlik katsayıları sırasıyla " $\alpha=.67, \alpha=.59, \alpha=$ .69" şeklindedir (Nazlıçiçek ve Erktin, 2002).

Bu araştırmada ise ölçeğin iç tutarlılık katsayısı " $\alpha=.80$ " hesaplanmıştır. Ölçeğin alt boyutları bakımından, matematikte algılanan başarı düzeyi, matematiğin yararları ve matematik dersine olan ilgi alt boyutları için güvenirlik katsayıları sırasıyla " $\alpha=.63, \alpha=.56, \alpha=.65$ " olarak bulunmuştur.

\section{Deneysel Süreç}

Araştırmanın deneysel aşaması 5 hafta ( 25 ders saati) yürütülmüştür. Stratejiler ve materyalleri tanımaya yönelik farkındalık programı ve ön test-son testleri uygulama süreleri de göz önüne alındığında, araştırma toplam olarak 32 ders saati sürmüştür. Deney ve kontrol gruplarındaki öğretim uygulamaları, öğretmen olan araştırmacı tarafindan gerçekleştirilmiştir. Gruplarda aynı problemlerle çalışılmış, çalışmaya paralel zamanlarda başlanmış ve bitirilmiştir.

Bu araştırma, materyal hazırlama ve yansıtıcı düşünme stratejilerinin belirlenmesi, pilot uygulama, farkındalık prog- 
ramı ve yansıtıcı düşünme etkinliklerinin uygulanması aşamalarında yürütülmüştür. Materyal hazırlama kapsamında, öncelikle matematik programı altıncı sınıf cebir öğrenme alanı kazanımları belirlenmiştir (MEB, 2013). Kazanımlarla ilgili çalışma kağıtlarında yer alan problemler hazırlanırken ders, çalışma ve öğretmen kılavuz kitabındaki (MEB, 2013) problemlerden yararlanılmış, bu problemlerle benzerlik gösteren ve kazanımlara uyan ek sorular da araştırmacılar tarafindan oluşturulmuştur. Çalışma yapraklarında yer alacak problemlerin belirlenmesinin ardından, öğrenme günlüğü, iki kolonlu öğrenme yazıları, yansıtıcı diyalog formu, hata değerlendirme formu, yönlendirme kartı materyalleri tasarlanmıştir. Bu materyallerin tasarlanması sürecinde öncelikle alan yazın taraması yapılmıştir. Yansıtıcı düşünme etkinlikleri ve içerik düzenlenirken başarılı sonuçlar ortaya koyan araşttrmalar (Brockbank ve McGill, 2006; Farah, 2012; Erdoğan, 2013; Ifenthaler, 2012; Moon, 2006; Wilson ve Jan, 1993) incelenmiştir. Materyaller uzman kanılarına da başvurmak suretiyle araştırmacılar tarafindan geliştirilmiştir. Hazırlanan materyaller matematik eğitimi alan uzmanlarının (1 profesör, 2 doçent) ve dil açısından ortaokulda görev yapan 2 Türkçe öğretmeninin görüşlerine sunulmuş; görüşler değerlendirilerek, cümle düşüklükleri, anlaşılması güç ifadeler ve yazım hatalarıyla ilgili düzenlemeler yapılmıştır.

Yansıtıcı düşünme becerisinin geliştirilmesi için aktif öğrenme ortamlarının oluşturulması ve buna uygun etkinliklerin gerçekleştirilmesi önemlidir (Taber, 2008). Bu bağlamda, araştırmada uygulanacak yansıtıcı düşünme becerisini geliştirmeye yönelik stratejiler belirlenirken öncelikle yansıtıcı düşünmeyle ilgili alan yazın taranmıştır. Araştırmalarda (Brockbank ve McGill, 2006; Davis, 2003; Erdoğan, 2013; Farrah, 2012; Moon, 2006, 2010; Pugalee, 2004, Taggart ve Wilson, 2005; Wilson ve Jan, 1993) uygulanan ve başarılı sonuçlar ortaya koyan stratejiler incelenmiştir. Bu araştırmada, matematik eğitimi alanında sıklıkla kullanılan ve öğrencilerin problem çözme becerilerini geliştirdiği vurgulanan, yazma, öğrenme günlüğü tutma, öğrenme yazıları, yansıtıcı diyalog, kendini değerlendirme, sorgulama, sesli düşünme stratejileri kullanılmıştır.

Araştırmada, çalışma grubu kapsamında yer almayan, cebir öğrenme alanında yer alan kazanımları bir önceki yıl görmüş 28 tane yedinci sınıf öğrenciyle pilot uygulama yapılmıştır. 8 ders saati süren pilot uygulama kapsamında, öğrencilere öğrenme günlüğü, iki kolonlu öğrenme yazıları, yansıtıcı diyalog formu, hata değerlendirme formu, yönlendirme kartı materyalleri dağıtımış, soruların ve ifadelerin ne anlama geldiği, materyalleri nasıl kullanacakları açıklanmıştır. Öğrencilere, uygulayacakları stratejiler (yazma, öğrenme günlüğü tutma, öğrenme yazıları, yansıtıcı diyalog, kendini değerlendirme, sorgulama, sesli düşünme) tanıtılmış ve bilgi verilmiştir. Öğrencilerden gelen sorular cevaplandırılmıştır. Öğrenciler yansıtıcı düşünme stratejilerinin uygulandığı etkinliklere katılmış ve materyalleri kullanmışlardır. Pilot uygulama sürecinde materyallerin ve etkinliklerin işlerliği, öğrenci dönütleri, anlaşılılığı göz önüne alınarak ifadeler revize edilmiştir.

Ön testin uygulanmasının ardından deney grubunda 5 ders saati süren farkındalık programı gerçekleştirilmiştir. Yansıtıcı düşünme etkinlikleri başlamadan önce öğrencilerin derslerde kullanılacak strateji ve materyallere yönelik farkındalıklarını geliştirmek amacıyla stratejiler ve materyaller ayrıntılı şekilde açıklanmıştır. Bu doğrultuda, araştırmanın amacı ve süresiyle ilgili bilgiler verilmiş, materyaller tanıtılarak öğrencilerin soruları yanıtlanmıştır. Farkındalık programının ardından, deney grubunda, yansıtıcı düşünme etkinliklerinin uygulanmasına geçilmiştir. Kontrol grubunda da deney grubuyla paralel zamanlarda ders kitabı ve öğretmen kitabına bağlı etkinlikler yapılmıştır. Deney grubunda uygulanan yansıtıcı düşünme stratejileri, gerçekleştirilen etkinlikler ve materyaller aşağıda açıklanmıştır.

Yazma: Farkındalık programında öğrencilere ders işleme süreçlerinde yaşadıkları deneyimleri, öğrendiklerini ve zihinlerinden geçen her şeyi materyallere yazmaları gerektiği vurgulanmıştır. Deneysel uygulama sürecinde öğrenciler etkinlikler boyunca uyguladıkları, düşündükleri ve yaptıkları her durumu çalışma kâğıtlarına yazmaları yönünde yönlendirilmiştir. Sınıf içinde ve dışında yansıtıcı düşünme becerisini geliştirmeye yönelik günlük, öğrenme yazıları, hata değerlendirme formu gibi materyaller alan yazın çerçevesinde yapılandırılarak yazma aktiviteleriyle öğrencilerin becerilerini geliştirmek amaçlanmıştır.

Öğrenme günlüğü tutma: Öğrencilerin ders sürecindeki deneyimlerini analiz etmelerine ve kendi ifadeleriyle yansıtmalarına olanak sağlamak amacıyla Erdoğan'ın (2013) çalışması temel alınarak “Öğrenme günlüğü" materyali tasarlanmıştır (Ek, 1). Her matematik dersi sonunda öğrencilerden bu günlükleri evde doldurmaları istenmiştir. Ertesi ders toplanan günlükler öğretmen tarafindan incelenmiş, gerekli durumlarda öğrencilere dönütler sunulmuştur.

Öğrenme yazıları: Bu araştırmada, öğrenme yazı çeşitlerinden “iki kolonlu öğrenme yazıları” uygulanmıştır. İki koIonlu öğrenme yazıları stratejisinin kullanılmasındaki amaç, öğrenmeye ilişkin bireysel tepki ve yansıtmaları kayıt altına almaktır. Bu doğrultuda, öğrencilerin çalışma yapraklarında iki kolon oluşturularak, etkinlik sonucu edindiği bilgileri ve öğretim etkinliğiyle ilgili yaşadığı güçlükleri yansıtmaları istenmiştir. Öğretmen tarafindan incelenen öğrenme yazılarıyla öğrencilerin neyi anlayıp anlamadıkları ve güçlük çektikleri yönler belirlenmiş, dönüt verilmiştir (Ek, 2). 
Yansıtıcı diyalog: Bu araştırmada, yansıtıcı diyalog stratejisi uygulanırken Brockbank ve McGill'in (2006) çalışması temel alınarak yapılandırımış bir "Yansıtıcı diyalog formu" geliştirilmiştir (Ek, 3). Yansıtıcı diyalog formu, öğrencilerin birbirlerine süreç odaklı sorular sormaları açısından yönlendirici olarak kullanılmıştı. Formdaki sorular, etkinlikler tamamlandıktan sonra ikili oturan öğrenciler tarafindan birbirilerine sorulmuş, yüksek sesle cevaplanması sağlanmıştır.

Kendini değerlendirme: Öğrenciler problemleri çözdükten sonra Erdoğan (2013) çalışması temel alınarak düzenlenen "Hata değerlendirme formu" materyalini doldurmuşlardır (Ek, 4). Kendini değerlendirme stratejisiyle, öğrencilerin öğrenme sürecindeki eksiklikleri ve hataları yansıtmaları, izleme becerilerinin gelişmesi amaçlanmıştır.

Sorgulama: Sorgulama stratejisi uygulanırken Erdoğan (2013) tarafindan geliştirilen "Yönlendirme kart" materyali kullanılmıştır. Öğrencilerden problem çözerken yönlendirme kartındaki soruları kendi kendilerine veya arkadaşlarına sormaları, problemleri adım adım çözmeleri istenmiştir. Yönlendirme kartının planlama bölümünde problemi çözmeden önce, izleme/planı devam ettirme bölümünde problem çözerken ve değerlendirme bölümünde problem çözümüne ulaştktan sonra yapılması gereken eylemleri ve cevaplanması gereken soruları bildiren ifadeler yer almaktadır (Ek, 5). Öğrencilerden, bireysel, arkadaşlarıly çiftli problem çözme süreçlerinde veya ev ödevlerini yaparken yönlendirme kartında yer alan soruları cevaplayarak ilerlemeleri istenmiştir. Böylece, öğrencilerin davranışlarında farkındalık kazanmaları, arkadaşlarına problem çözme aşamalarını yansıtmaları amaçlanmıştır.

Sesli düşünme: Bu araştırmada, öğrencilerin yönlendirme kartyyla problem çözerken, yansıtıcı diyaloglar kurarken sesli düşünmeleri ve düşüncelerini açık bir dille arkadaşlarına açıklamaları istenmiştir. Ayrıca, öğretmen konu sunumu sürecinde tüm sınıfa model olarak problem çözme sürecini sesli düşünerek yansıtmıştır.

Kontrol grubunda herhangi bir öğretim planlaması yapılmamış; mevcut matematik dersi öğretim programı, öğretmen kılavuz kitabı ve öğrenci ders kitabı göz önüne alınarak matematik öğretimi gerçekleştirilmiştir. Kontrol grubundaki öğrenciler, matematik programı kapsamında altıncı sınıf cebir öğrenme alanı kazanımları dikkate alınarak, deney grubuyla aynı problemler üzerinde çalışmışlardır. Öğretmen, matematik dersi öğretim programı ve öğretmen kılavuz kitabını göz önüne alarak konu sunumu yapmışttr. Öğretmen ders sürecinde, deney grubunda kullanılan problemlerin aynısını kendisi çözmüş veya problemleri, problem çözme basamaklarına göre soru-cevap yöntemiyle öğrencilere yöneltmiştir. Ders bitiminde, öğrencilerin eksik öğrenmelerini tamamlamak amacıyla, öğrencilere anlamadıkları konular, kavramlar veya çözemedikleri problem durumları sorulmuştur. Zorlanılan problemler öğretmen veya başka bir öğrenci tarafindan tahtada çözülmüştür. Konu sonlarında, konu özeti öğretmen tarafindan veya öğrenciler tarafindan yapılmıştır. Dolayısıyla, deney grubundan farklı bir öğrenme ortamı olduğu söylenebilir.

\section{Veri Analizi}

Veri analizinde, öncelikle, parametrik testlerin gerektirdiği temel varsayımlar incelenmiştir. Bu doğrultuda, bağımlı değişkene ait her bir düzeyde, deney ve kontrol grubu için dağılımların normalliği analiz edilmiştir. Grup büyüklükleri 50'den küçük olduğu için normal dağılımla ilgili analiz yapmak amacıyla Shapiro-Wilks testi uygulanmıştır. Veriler çözümlenirken, veri türüne bağlı olarak, grupların ön test puanlarının karşılaştırılmasında bağımsız grup t-testi ve aynı grup içindeki ön test-son test puanlarının karşılaştırılmasında bağımlı grup t-testi kullanılmıştır.

Ön test-son test desenine sahip araştırmalarda, iki farklı müdahalenin etkilerini kıyaslamak amacıyla kovaryans analizi (ANCOVA) kullanılabilir. Ön testten alınan puanlar, gruplar arasında zaten var olan farkları kontrol altında tutmak için bir kovaryet olarak alınır (Pallant, 2016). Bu bağlamda, grupların son test puanları arasındaki farkı incelemek amacıyla tek faktörlü kovaryans analizi (ANCOVA) uygulanmıştır. Düzeltilmiş puanlar arasındaki farkın kaynağını belirlemek amacıyla Bonferroni testi kullanılmıştr. ANCOVA öncesinde, normallik, bağımlı değişken ile kovaryet arasındaki doğrusal ilişki, regresyon eğimlerinin homojenliği, varyansın homojenliği varsayımları incelenmiştir. Araştırma sürecinde anlamlılık düzeyi $p<.05$ olarak alınmıştr.

\section{Bulgular}

Bu kısmında, deney ve kontrol grubunun MTÖ ön ve son test puanlarının analizlerinden elde edilen bulgular verilmiştir. Testlerin analizlerinde öncelikle puanların normal dağılım sergileme durumları Shapiro-Wilks testiyle analiz edilmiş ve sonuçlar Tablo 1'de gösterilmiştir. 
Tablo 1. MTÖ’ye ilişkin shapiro-wilks normallik sonuçları

\begin{tabular}{lcccc}
\hline \multirow{2}{*}{ Grup } & \multicolumn{2}{c}{ Ön test } & \multicolumn{2}{c}{ Son test } \\
\cline { 2 - 5 } & Shapiro-Wilks & $\mathrm{p}$ & Shapiro-Wilks & $\mathrm{p}$ \\
\hline Deney & .95 & .09 & .95 & .12 \\
Kontrol & .95 & .12 & .96 & .25 \\
\hline
\end{tabular}

Tablo 1 incelendiğinde, deney grubunun Shapiro-Wilks Testi normallik sonuçları, MTÖ ön test puanları için ( $w=.95$, $\mathrm{p}=.09>.05)$ ve MTÖ son test puanları için $(\mathrm{w}=.95, \mathrm{p}=.12>.05)^{\prime}$ 'dir. Kontrol grubunun Shapiro-Wilks Testi normallik sonuçları, MTÖ ön test puanları için $(w=.95, p=.12>.05)$ ve MTÖ son test puanları için $(w=.96, p=.25>.05)^{\prime}$ dir. Bu bulgulardan yola çıkarak, test puanlarının normal dağılım gösterdiği saptanmıştır.

Deney grubunda uygulanan yansıtıcı düşünme etkinliklerinden önce, çalışma gruplarının MTÖ ön test puanları bağımsız grup t-testi ile incelenmiş ve sonuçlar Tablo 2'de verilmiştir.

Tablo 2. MTÖ ön test puanlarının karşılaştırılmasına yönelik bağımsız grup t-testi sonuçları

\begin{tabular}{lcccccc}
\hline Grup & $\mathrm{N}$ & $\bar{X}$ & $\mathrm{ss}$ & $\mathrm{sd}$ & $\mathrm{t}$ & $\mathrm{p}$ \\
\hline Deney grubu & 37 & 62.08 & 14.33 & 70 & -.341 & .734 \\
Kontrol grubu & 35 & 63.14 & 11.92 & & & \\
\hline
\end{tabular}

Tablo 2 göz önüne alındığında, deney ve kontrol gruplarının MTÖ ön test puanları arasında anlamlı bir farklılık olmadığı görülmüştür $\left[\mathrm{t}_{(70)}=-.34, p>\right.$.05]. Bu bulgu göz önüne alınarak, yansıtıcı düşünme etkinlikleri öncesi çalışma gruplarındaki öğrencilerin matematik tutumları arasında anlamlı bir farklılık olmadığı söylenebilir.

Araştırmada, deney grubunda gerçekleştirilen yansıtıcı düşünme etkinlikleri sonrasında, MTÖ ön ve son test puanları bağımlı grup t-testi aracılığıyla kıyaslanmış, sonuçlar Tablo 3'te sunulmuştur.

Tablo 3. Deney grubu MTÖ ön ve son test puanlarına yönelik bağımlı grup t-testi sonuçları

\begin{tabular}{lcccccc}
\hline Ölçüm & $\mathrm{N}$ & $\bar{X}$ & $\mathrm{ss}$ & $\mathrm{sd}$ & $\mathrm{t}$ & $\mathrm{p}$ \\
\hline Ön test & 37 & 62.08 & 14.33 & 36 & -4.505 & .000 \\
Son test & 37 & 78.22 & 14.78 & & & \\
\hline
\end{tabular}

Tablo 3 göz önüne alındığında, deney grubunun MTÖ son test ortalamasının ön test ortalamasına kıyasla yüksek olduğu saptanmıştır. Deney grubunun MTÖ ön ve son test puanlarına yönelik uygulanan bağımlı grup t-testi analizi sonucunda istatistiksel olarak anlamlı bir farklılık elde edilmiştir $\left[\mathrm{t}_{(36)}=-4.51, \mathrm{p}<.05\right]$. Bu farklıığın, son test lehine bir farklılık olduğu belirlenmiştir.

Kontrol grubunda gerçekleştirilen öğretim uygulamalarından sonra, MTÖ ön ve son test puanları bağımlı grup t-testi kullanılarak karşılaştrıımış, sonuçlar Tablo 4'te verilmiştir.

Tablo 4. Kontrol grubu MTÖ ön ve son test puanlarına yönelik bağımlı grup t-testi sonuçları

\begin{tabular}{lcccccc}
\hline Ölçüm & $\mathrm{N}$ & $\bar{X}$ & $\mathrm{ss}$ & $\mathrm{sd}$ & $\mathrm{t}$ & $\mathrm{p}$ \\
\hline Ön test & 35 & 63.14 & 11.92 & \multirow{2}{*}{34} & -.894 & .377 \\
Son test & 35 & 66.31 & 14.83 & & & \\
\hline
\end{tabular}

Tablo 4 incelendiğinde, kontrol grubunun MTÖ son test ortalamasının ön test ortalamasına kıyasla yüksek olduğu belirlenmiştir. Ancak, kontrol grubunun MTÖ ön ve son test puanlarına yönelik uygulanan bağımlı grup t-testi sonucuna göre istatistiksel açıdan anlamlı bir farklılık tespit edilememiştir $\left[\mathrm{t}_{(34)}=-.89, \mathrm{p}>\right.$.05].

Araştırmada, başlangıçtaki ön test puanları kontrol altında tutulduktan sonra deney ve kontrol grubu için MTÖ son test ortalama puanlarının farklı olup olmadığını incelemek amacıyla ANCOVA yürütülmüştür. Ancak, ANCOVA'yı uygulamadan önce ANCOVA varsayımları incelenmiş̧tir. İlk varsayım olan verilerin normal dağılımı, Shapiro-Wilks testiyle incelenmiş ve bulgular Tablo 1'de sunulmuştur. MTÖ ön test ve son test puanlarının normal dağılıma sahip olduğu görülmüştür. Doğrusallık yani bağımlı değişken (MTÖ son test puanları) ile kovaryet (MTÖ ön test puanları) arasındaki doğrusal ilişki varsayımını kontrol etmek amacıyla grupların her biri için puanların genel dağılımı saçılım grafiğiyle incelenmiş, her bir grup için bağımlı değişken ile kovaryet arasında doğrusal bir ilişki tespit edilmiştir. Daha sonra, ANCOVA'nın temel varsayımlarından biri olan regresyon eğimlerinin homojenliği varsayımının karşılanıp karşılanmadığı analiz 
edilmiş ve sonuçlar Tablo 5'te gösterilmiştir.

Tablo 5. MTÖ’ye yönelik regresyon eğimi

\begin{tabular}{lccccc}
\hline Kaynak & Kareler Toplamı & sd & Kareler Ortalaması & $\mathrm{F}$ & $\mathrm{p}$ \\
\hline Düzeltilmiş model & 3026.603 & 3 & 1008.868 & 4.614 & .005 \\
Sabit & 20503.682 & 1 & 20503.682 & 93.781 & .000 \\
Grup & 3.376 & 1 & 3.376 & .015 & .901 \\
Ön test & 464.542 & 1 & 464.542 & 2.125 & .150 \\
Grup*Ön test & 67.446 & 1 & 67.446 & .308 & .580 \\
Hata & 14867.050 & 68 & 218.633 & & \\
Toplam & 395619.000 & 72 & & & \\
Düzeltilmiş toplam & 17893.653 & 71 & & & \\
\hline
\end{tabular}

Tablo 5'e göre, kovaryet ile son test puanlarının istatistiksel olarak anlamlı bir etkileşim göstermediği saptanmıştır $\left[F_{(1,68)}=.31, p=.58>.05\right]$. Bu bulgu, regresyon eğimlerinin homojenliği varsayımının sağlandığını göstermektedir.

Ayrıca, varyansların homojenliği varsayımını incelemek amacıyla Levene's Testi yürütülmüş ve gruplar arası varyansların homojen olduğu belirlenmiştir ( $F=.02, p=.88>.05)$. Bulgulara göre, ANCOVA varsayımlarının sağlandığı görülmüştür. Buradan hareketle, grupların ön test puanları kontrol edilirken düzeltilmiş son test puanları arasında anlamlı bir fark olup olmadığını belirlemek amacıyla ANCOVA uygulanmış ve sonuçlar Tablo 6'da verilmiştir.

Tablo 6. Grupların düzeltilmiş MTÖ son test puanlarına yönelik ANCOVA sonuçları

\begin{tabular}{lccccc}
\hline Varyansın Kaynağı & Kareler Toplamı & sd & Kareler Ortalaması & $F$ & $p$ \\
\hline Ön test (Reg.) & 411.317 & 1 & 411.317 & 1.900 & .172 \\
Grup & 2461.049 & 1 & 2461.049 & 11.370 & .001 \\
Hata & 14934.496 & 69 & 216.442 & & \\
Toplam & 395619.000 & 72 & & & \\
\hline
\end{tabular}

Tablo 6'ya göre, deney ve kontrol gruplarının MTÖ ön test puanları kontrol edilirken, düzeltilmiş MTÖ son test ortalama puanları arasında anlamlı bir farklılık bulunmuştur $\left[\mathrm{F}_{(1,69)}=11.37, \mathrm{p}<.05\right]$. Bu farklılık deney grubu lehinedir. Grupların düzeltilmiş MTÖ son test ortalama puanları için uygulanan Bonferroni testi sonuçları incelendiğinde, deney grubundaki öğrencilerin matematik tutumlarının $(\bar{x}=78.12)$, kontrol grubundaki öğrencilerin matematik tutumlarından $(\bar{x}=66.41)$ daha yüksek olduğu belirlenmiştir.

\section{Sonuç ve Tartışma}

Bilişsel ve duyuşsal süreçlerin öğrenmenin önemli bileşenleri olduğu göz önüne alındığında öğrencilerin matematiğe yönelik tutumlarını geliştirmenin önemli olduğu açıktır. Bu bağlamda, yansıtıcı düşünme etkinliklerinin altıncı sınıf öğrencilerinin matematik tutumuna etkisinin incelendiği bu araştırmada, deney ve kontrol grubundaki öğrencilerin MTÖ ön test puan ortalamaları arasında istatistiksel olarak anlamlı bir farklılık tespit edilememiştir. Bu bulgudan hareketle, deney grubunda uygulanan yansıtıcı düşünme etkinliklerinden önce, çalışma gruplarındaki öğrencilerin matematik tutum seviyelerinin denk olduğu söylenebilir.

Araştırmada; bağımlı grup t-testi analizinden elde edilen bulgulara göre, deney grubunda gerçekleştirilen yansıticı düşünme etkinlikleri sonrasında, deney grubunun MTÖ son test puan ortalamasının, ön test puan ortalamasına göre anlamlı derecede yüksek olduğu sonucuna ulaşıımıştır. Bu sonuç, sınıf içinde öğrenciyi aktif kılan ve sorgulamaya yönelten etkinliklerin öğrencilerin matematik tutumları üzerindeki etkisini inceleyen araştırma bulgularıyla paralellik göstermektedir (Eshun, 2004; Hodges ve Kim, 2013). Eshun (2004) çalışmasında, öğrencilerin matematik tutumlarının yaşadıkları deneyimlerden etkilendiğini ve öğrenme sürecine aktif katılan öğrencilerin matematik tutumlarının olumlu yönde geliştiğini bildirmiştir. Hodges ve Kim (2013) matematik derslerinde öğrencilerin problem çözme sürecinde sorgulamalar yapmalarını sağlayacak etkinliklerin, matematik tutumlarını pozitif etkilediğini ortaya koymuşlardır.

Bu araştırmada, deney grubundaki öğrenciler yansıtıcı düşünme etkinlikleriyle yansıtmalar yaparak derse aktif katılmaları yönünde desteklenmiştir. Yansıtıcı diyalog ve sorgulama stratejilerinde öğrenciler akranlarıyla sorgulamalar yapmaları yönünde teşvik edilmiştir. Öğrencilerin yansıtıcı diyalog formu ve yönlendirme kart materyallerini kullanmaları sağlanmıştr. Öğrencilerin yansıtıcı düşünme stratejileri aracılı̆̆ıyla iletişim ve sosyal etkileşim açısından desteklenmesi- 
nin, matematik tutumları üzerinde olumlu etki sağladığı söylenebilir. Daha önce yapılan araştırma bulguları bu görüşü destekler niteliktedir. Bu doğrultuda, Tichenor ve Plavchan (2010) matematik öğrenme ortamlarının sosyal etkileşim sağlayacak şekilde düzenlenmesinin öğrencilerin matematik tutumunu geliştirmede etkili olduğunu vurgulamışlardır. Mata, Monteiro ve Peixoto (2012) çalışmalarında öğrencilerin sosyal yönden desteklendiği öğrenme ortamlarının matematik tutumları üzerinde pozitif etkileri olduğunu tespit ederken, Samuelsson ve Granström (2007) sosyal yönden destekleyici olmayan sınıf ikliminin matematik tutumlarını olumsuz etkilediğini bildirmişlerdir.

Araştırma bulgularına göre, kontrol grubuna ait MTÖ ön test ve son test puan ortalamaları arasında anlamlı bir farklılık tespit edilmemiştir. Bu bulgudan hareketle, kontrol grubunda matematik dersi öğretim programı, öğretmen kılavuz kitabı ve öğrenci ders kitabı göz önüne alınarak yürütülen matematik derslerinin öğrencilerin matematik tutumlarının gelişmesine katkıda bulunmadığı söylenebilir.

Araştırmada ulaşılan bir diğer önemli bulgu olarak, deney ve kontrol gruplarının ön test puanları kontrol edilirken düzeltilmiş MTÖ son test ortalama puanları arasında anlamlı bir farklılık bulunmuştur. Bu farklılığın deney grubu lehine olduğu tespit edilmiştir. Araştırmadan elde edilen bu sonuç göz önüne alındığında, yansıtıcı düşünme etkinliklerinin öğrencilerim matematik tutumları üzerinde pozitif etkisinin olduğu söylenebilir. Yansıttcı düşünme becerilerinin geliştirilmesinde etkinliklerin önemli rolü olduğu göz önüne alındığında (Taber, 2008), araştırmada uygulanan, öğrencileri aktif kılan ve yansıtmaya sevk eden etkinliklerin öğrencilerin matematik tutumlarının gelişmesine katkı sağladığı ifade edilebilir. Yansıtıcı düşünme etkinliklerinin öğrencilerin derse yönelik tutumlarını pozitif etkilediğini ortaya koyan araştırma bulguları bu sonucu desteklemektedir (Baş ve Beyhan, 2012; Demirel vd., 2015; Tok, 2008; Grossman, 2009; Moon, 2006; Phan, 2009; Uygun ve Çetin, 2014; Wilson ve Jan, 1993). Wilson ve Jan (1993) çalışmalarında yansıtıcı düşünme etkinliklerinin uygulandığı süreçte oluşan pozitif öğrenme ortamının, öğrencilerin düşüncelerini ve görüşlerini rahat bir şekilde yansıtabilmelerine olanak sağladığını belirtmiştir.

Grossman (2009) ve Moon'un (2006) araştırma bulguları, araştırmanın yansıtıcı düşünme etkinliklerinin öğrencilerin matematik tutumları üzerinde pozitif etkisi olduğu bulgusuyla örtüşmektedir. Grossman (2009) çalışmasında yansıtıcı düşünme becerisini kazandırma sürecinin zor olduğunu ve öğrencileri sorgulama, izleme ve yansıtmaya yönelten tasarımların gerekliliğini vurgulamıştır. Bu tasarımların öğretim ortamlarında kullanılmasının öğrencilerin duyuşsal becerilerinin gelişmesine de olumlu etkisi olduğunu ifade etmiştir. Moon (2006) ise yansıtıcı düşünme becerisinin öğrencilerin tutumlarının gelişmesine katkı sağladığını bildirmiştir. Daha önce farklı derslerde yürütülen araşttrmalarda, yansıtıcı düşünme etkinliklerinin İngilizce (Baş ve Beyhan, 2012), fen bilgisi (Tok, 2008), sosyal bilgiler (Uygun ve Çetin, 2014) gibi derslere yönelik öğrenci tutumlarını olumlu yönde geliştirdikleri vurgulanmıştır. Bu araştırmada ulaşılan, yansıtıcı düşünme etkinliklerinin öğrencilerin matematik tutumlarını anlamlı düzeyde yükselttiği bulgusu, daha önce yapılan araştırmaları destekler niteliktedir.

Araştırmada uygulanan yazma, öğrenme günlüğü tutma ve öğrenme yazıları gibi stratejilerle öğrencilerin öğrenme süreçleri yanında duygularını da yansıttıkları, dolayısıyla bu stratejilerin öğrencilerin matematik tutumlarını geliştirmede olumlu etkileri olduğu söylenebilir. Mevcut araştrrmadan elde eldilen bu sonucun, daha önce yapılan araştrma sonuçlarıyla tutarlı olduğu görülmektedir (Burton, 2009; Can ve Altuntaş, 2016; Farrah, 2012; Graham, 2003; Inoue ve Buczynski, 2011; Walker, 2006). Burton (2009) yazmanın, hem öğrenmeye ve yansıttcı düşünme becerisinin gelişmesine destek olan hem de öğrencilerin hoşlandığı bir etkinlik olduğunu belirtmiştir. Can ve Altuntaş (2016) araştırmaları sonucunda, yansıtıcı günlük yazma etkinliğinin öğrencilerin derse karşı olumlu tutum geliştirmelerine destek olan bir uygulama olduğunu bildirmişlerdir. Farrah (2012) da yazma etkinliği konusunda yaptiğı çalışmasında, günlük yazmanın öğrencilere öğrendiklerini tekrar etme, bilgiler arasında bağ kurma, hayal gücünü ve olumlu tutum geliştirme gibi birçok faydası olduğunu ifade etmiştir. Bu konuda yapılan benzer çalışmalarda, Graham (2003) öğrencilerin yazma etkinlikleri sürecinde özgüvenlerinin geliştiğini ve eğlendiklerini, Inoue ve Buczynski (2011) öğrencilerin matematik derslerinde yazma stratejisi aracılığıyla, problem çözme sürecinde kullandıkları stratejileri ve süreçleri izleyip yansıtthklarını, matematiksel kavramları daha iyi anlayarak derse ilgilerinin arttğını ifade etmişlerdir. Walker (2006) ise yansıttcı günlük yazma etkinliğinin öğrencilerin duygu ve düşüncelerini ifade etmelerini kolaylaştırdığını ve bu durumun olumlu duyuşsal kazanımlara yol açthğını belirtmiştir.

\section{5. Öneriler}

Alan yazında çeşitli araştırmalarda kullanılan yansıtıcı düşünme becerisini geliştirmeye yönelik stratejilerin yalnız kullanıldıklarında bazı avantajlara ve dezavantajlara sahip oldukları çeşitli araştırmalarda bildirilmiştir (Can ve Altuntaş, 2016; Hartman, 2001; Pugalee, 2004). Sesli düşünme stratejisi yansıtma yapmada önemlidir, ancak uygulama sürecinde yazma stratejisine kıyasla daha fazla zaman alır (Hartman, 2001). Yazma stratejisinin sınıf mevcudunun fazla olduğu du-

| Kastamonu Eğitim Dergisi, 27(1), 2019| 
rumlarda uygulanmasının daha kolay olduğu (Pugalee, 2004), ancak yansıtıcı günlük yazmanın öğrencilere zor ve zaman alıcı gelebileceği belirtilmiştir (Can ve Altuntaş, 2016). Bu araştırmada, yansıtıcı düşünme stratejileri birbirlerini tamamlayıcı nitelikte uygulanmıştır. Ayrıca, yapılandırılmış materyallerin kullanılmasının öğrencilerin yansıtma yapmalarını da kolaylaştırdığı düşünülmektedir. Bu konuda Gorlewski ve Greene (2011) yapılandırılmış günlüklerin yazma becerisinin geliş̧mesini kolaylaştırdığını belirtmişlerdir. İleriki araştırmalarda, farklı yansıtıcı düşünme stratejileri karşılaştrılarak, avantaj ve dezavantajlarının tartışılmasının faydalı olabileceği düşünülmektedir.

Yapılandırmacı yaklaşıma göre eğitimin temel amaçlarından biri yansıtıcı düşünmeyi gerçekleştirmektir (Mahnaz, 1997). Lebow (1993) bu konuda yapılandırmacı yaklaşımın gerektirdiği öğretme-öğrenme sürecinde, öğrencilerin sorumluluk bilincini ve tutumlarını geliştirmeye yönelik destekleyici ortamlar oluşturmanın önemli olduğunu vurgulamıştr. Yapılandırmacı yaklaşıma göre geliştirilen matematik programında (MEB, 2013) öğrencilerin üst düzey düşünme becerilerine sahip olması hedeflenmektedir. Ancak, bu becerileri geliştirmeye yönelik strateji, etkinlik ve materyallere yeterince yer verilmediği söylenebilir. Dolayısıyla, program geliştirme aşamalarında öğrencilerin yansıtıı düşünme becerilerini geliştirmeye yönelik materyal ve etkinliklerin yer almasının faydalı olacağı ifade edilebilir. Bu araştırmada uygulanan, yansıtıcı diyalog gibi stratejilerin matematik ders içeriğiyle bütünleştirilmesinin programın yapılandırılmasına katkı sağlayacağı düşünülebilir.

Bu araştırmadan elde edilen bulgulara göre, öğrencilerin matematiğe yönelik olumlu tutumlar geliştirmelerini sağlamak amacıyla yansıtıcı düşünme etkinlikleri uygulanabilir. Ancak, bu araştırma altıncı sınıf seviyesiyle ve cebir öğrenme alanında yer alan konularla sınırlıdır. Farklı matematik konularını ve sınıf seviyelerini ele alan deneysel araştırmalar yapılabilir. Yansıtıcı düşünme stratejilerinin matematik tutumu dışında başarı, üstbilişsel beceri, kaygı gibi değişkenler üzerindeki etkilerini inceleyen araştırmalar yapılabilir. Yapılacak araştırmalarda, nitel yaklaşımlar kullanılarak daha ayrıntılı analizler sunulabilir.

Öğrencilerin yansıtıcı düşünme becerisine sahip olabilmeleri için öncelikle öğretmenlerin yansıtıcı düşünme becerisine sahip olmaları gerekmektedir. Yansıtıcı düşünme becerisine sahip öğretmenler öğrencileri destekler ve yönlendirir (Wilson ve Jan, 1993). Dolayısıyla, öğrencilerin yansıtıcı düşünme becerilerinin geliştirilmesi için etkinliklerin uygulayıCıSı olan öğretmenlerin ve öğretmen adaylarının hizmet içinde ve hizmet öncesinde yansıtıcı düşünme alanında yetiştirilmesi önerilmektedir.

\section{Kaynakça}

Aryani, F., Rais, M., \& Wirawan, H. (2017). Reflective learning model in improving student critical thinking skills. Global Journal of Engineering Education, 19(1), 19-23.

Baki, A., Güç, F. A., \& Özmen, Z. M. (2012). İlköğretim matematik öğretmeni adaylarının problem çözmeye yönelik yansıtıcı düşünme becerilerinin incelenmesi. Uluslararası Eğitim Programları ve Öğretim Çalışmaları Dergisi, 2(3), 59-72.

Baş, G., \& Beyhan, Ö. (2012). İngilizce dersinde yansıtıcı düşünme etkinliklerinin öğrencilerin akademik başarılarına ve derse yönelik tutumlarına etkisi. Amasya Üniversitesi Eğitim Fakültesi Dergisi, 1(2), 128-142.

Baş, G., \& Kıvılcım, Z. S. (2013). Lise öğrencilerinin problem çözmeye yönelik yansıtıcı düşünme becerileri ile matematik ve geometri derslerindeki akademik başarıları arasındaki ilişki. Ahi Evran Üniversitesi Kırşehir Eğitim Fakültesi Dergisi (KEFAD), $14(3), 1-17$.

Beveridge, I. (1997). Teaching your students to think reflectively: The case for ref-lective journals. Teaching in Higher Education, 2(1), 33-43. Brockbank, A., \& McGill, I. (2006). Facilitating reflective learning through mentoring and coaching. London, Philadelphia, PA: Kogan Page.

Burton, J. (2009). Reflective writing: Getting to the heart of teaching and learning. In J. Burton, P. Quirke, C. L. Reichmann, \& J. K. Peyton (Eds.), Reflective writing: A way to lifelong teacher learning (pp. 1-11). TESL-EJ Publications.

Can, R., \& Altuntaş, B. (2016). Yansıtıcı günlük yazma uygulamasına ilişkin öğrenci görüşleri. Ana Dili Eğitimi Dergisi, 4(1), 53-63.

Caine, R. N., \& Caine, G. (1991). Making connections: Teaching and the human brain. Alexandria, VA: Association for Supervision and Curriculum Development.

Choy, S. C., \& Oo, P. S. (2012). Reflective thinking and teaching practices: A precursor for incorporating critical thinking into the classroom. International Journal of Instruction, 5(1), 167-182.

Cohen, J. (1988). Statistical power analysis for the behavioral sciences (2nd ed.). Hillsdale, NJ: Lawrence Earlbaum Associates.

Creswell, J. W. (2013). Research design: Qualitative, quantitative, and mixed methods approaches. Thousand Oaks, CA: Sage.

Davis, E. (2003). Prompting middle school science students for productive reflection: Generic and directed prompts. Journal of the Learning Sciences, 12(1), 91-142.

Demirel, M., Derman, İ., \& Karagedik, E. (2015). A study on the relationship between reflective thinking skills towards problem solving and attitudes towards Mathematics. Procedia - Social and Behavioral Sciences, 197, 2086-2096. 
Dewey, J. (1933). How we think. Boston: Heath \& CO.

Epstein, A. S. (2003). How planning and reflection develop young children's thinking skills. Young Children, 58(5), 28-36.

Erdoğan, F. (2013). Matematik öğretiminde üstbilişsel stratejilerle desteklenen işbirlikli öğrenme yönteminin 6. sınıf öğrencilerinin akademik başarıları, üstbilişsel becerileri ve matematik tutumuna etkisinin incelenmesi (Yayımlanmamış doktora tezi). Marmara Üniversitesi: İstanbul.

Eshun, B. A. (2004). Sex-differences in attitude of students towards mathematics in secondary schools. Mathematics Connection, 4(1), 1-3.

Farrah, M. (2012). Reflective journal writing as an effective technique In the writing process. An-Najah University Journal for Research - Humanities, 26(4), 997-1025.

Fraser, B. J., \& Kahle, J. B. (2007). Classroom, home and peer environment influences on student outcomes in science and mathematics: An analysis of systemic reform data. International Journal of Science Education, 29(15), 1891-1909.

Garcia, M., Sanchez, V., \& Escudero, I. (2007). Learning through reflection in mathematics teacher education. Educational Studies in Mathematics, 64(1), 1-17.

Gorlewski J., \& Greene K. (2011). Research for the classroom: The power of reflective writing. The English Journal, 100(4), 90-93.

Graham. L. (2003). Writing journals: An investigation. Reading Literacy and Language, 37(1), 39-42.

Grossman, R. (2009). Structures for facilitating student reflection. College Teaching, 57, 15-22.

Grossman, S., \& Williston, L. (2001). Strategies for teaching early childhood students to connect reflective thinking to practice. Childhood Education, 7(4), 236-240.

Hartman, H. J. (2001). Developing students' metacognitive knowledge and strategies. In H. J. Hartman (Ed.), Metacognition in learning and instruction: Theory, research, and practice (pp. 33-68). London-The Netherlands: Kluwer Academic Publishers. Chapter 8 Dordrecht.

Hinett, K. (2002). Developing reflective practice in legal education. UK: Centre for Legal Education.

Hodges, C. B., \& Kim, C. (2013). Improving college students' attitudes toward mathematics. Tech Trends: Linking Research and Practice to Improve Learning, 57(4), 59-66.

Ifenthaler, D. (2012). Determining the effectiveness of prompts for self-regulated learning in problem-solving scenarios. Educational Technology \& Society, 15(1), 38-52.

Inoue, N., \& Buczynski, S. (2011). You asked open-ended questions, now what? Understanding the nature of stumbling blocks in teaching inquiry lessons. The Mathematics Educator, 20(2), 10-23.

Incikabi, L., Tuna, A., \& Biber, A. C. (2013). An analysis of mathematics teacher candidates' critical thinking dispositions and their logical thinking skills. Journal of International Education Research (JIER), 9(3), 257-266.

Kandemir, M. A. (2015). illköğretim matematik ve sınıf öğretmeni adaylarının yansıtıcı düşünme eğilim düzeylerinin bazı değişkenlere göre incelenmesi. NWSA-Education Sciences, 10(4), 253-275.

Kızılkaya, G. (2009). Yansıtıcı düşünme etkinlikleri ile desteklenmiş web tabanli öğrenme ortamlarinin problem çözme üzerine etkisi (Yayımlanmamış doktora tezi). HacettepeÜniversitesi: Ankara.

Kızılkaya, G., \& Aşkar, P. (2009). Problem çözmeye yönelik yansıtıcı düşünme becerisi ölçeğinin geliştirilmesi. Eğitim ve Bilim, $34(154), 82-92$.

King, F. J., Goodson, L., \& Rohani, F. (2013). Higher order thinking skills. Center for advancement of learning and assessment. http:// www.cala.fsu.edu/files/higher_order_thinking_skills.pdf adresinden erişildi.

Kramarski, B., \& Kohen, Z. (2017). Promoting preservice teachers' dual self-regulation roles as learners and as teachers: Effects of generic vs. specific prompts. Metacognition Learning, 12(2), 157-191.

Kramarski, B., Weiss, I., \& Sharon, S. (2013). Generic versus context-specific prompts for supporting selfregulation in mathematical problem solving among students with low or high prior knowledge. Journal of Cognitive Education and Psychology, 12(2), $197-214$.

Lebow, D. (1993). Constructivist values for instructional systems design: Five principles toward new mindset. Educational Technology Research and Development, 41(3), 4-16.

Lin, X. D., Hmelo, C., Kinzer, C. K., \& Secules, T. J. (1999). Designing technology to support reflection. Educational Technology Research and Development, 47(3), 43-62.

Lindh, I., \& Thorgren, S. (2016). Critical event recognition: An extended view of reflective learning. Management Learning, 47(5), 525-542.

Mahnaz, M. (1997). Content and nature of reflective teaching: A case of an experiment middle school science teacher. Clearing House, 70(3), 143-151.

Mata, M. L., Monteiro, V., \& Peixoto, F. (2012). Attitudes towards mathematics: Effects of individual, motivational, and social support factors. Child Development Research, 2, 1-10.

Mayes, R., Chase, P. N., \& Walker, V. L. (2008). Supplemental practice and diagnostic assessment in an applied college algebra course. Journal of College Reading and Learning, 38(2), 7-30.

McLeod, D. B. (1992). Research on affect in mathematics education: A reconceptualisation. In D. A. Grouws (Ed.), Handbook of research on mathematics teaching and learning (pp. 575-596). New York, NY: Macmillan Publishing Company.

McNaught, K. (2010). Reflective writing in mathematics education programmes. Reflective Practice, 11(3), 369-379.

Mezirow, J. (1991). Transformative dimensions of adult learning. San Francisco:Jossey-Bass. 
Milli Eğitim Bakanlığı (2013). Ortaokul matematik dersi (5-6-7-8. sınıflar) öğretim programı. Ankara: MEB Yayınları.

Mohamed, L., \& Waheed, H. (2011). Secondary students' attitude towards mathematics in a selected school of Maldives. International Journal of Humanities and Social Science, 1(15), 277-281.

Moon, J. A. (2006). Learning journals: Handbook for reflective practice and professional development. London: Routledge.

Moon, J. (2010). Learning journals and logs. Ucd teaching and learning/resources. http://ar.cetl.hku.hk/pdf/ucdtla0035.pdf adresinden erişildi.

Muzzatti, B., \& Agnoli, F. (2007). Gender and mathematics: Attitudes and stereotype threat susceptibility in Italian children. Developmental Psychology, 43(3), 747-759.

Nazlıçiçek. N., \& Erktin, E. (2002). illköğretim matematik öğretmenleri için kısaltılmış matematik tutum ölçeği. http://www.fedu.metu. edu .tr/ufbmek-5/b_kitabı adresinden erişildi.

Neale, D. (1969). The role of attitudes in learning mathematics. The Arithmetic Teacher, 16(8), 631-641.

Pallant, J. (2016). SPSS kullanma kılavuzu. (Çev. Sibel Balcı ve Berat Ahi) Ankara: Anı Yayıncılık.

Phan, H. P. (2009). Exploring students' reflective thinking practice, deep processing strategies, effort, and achievement goal orientations. Educational Psychology, 29(3), 297-313.

Pimta, S., Tayruakham, S., \& Nuangchalerm, P. (2009). Factors influencing mathematic problem-solving ability of sixth grade students. Journal of Social Science, 5(4), 382-385.

Pugalee D. K. (2004). A comparison of verbal and written descriptions of students' problem solving processes. Educational Studies in Mathematics, 55, 27-47.

Samuelsson, J., \& Granström, K. (2007). Important prerequisites for students' mathematical achievement. Journal of Theory and Practice in Education, 3(2), 150-170.

Saygılı, G., \& Atahan, R. (2014). Üstün zekâlı çocukların problem çözmeye yönelik yansıtıcı düşünme becerilerinin çeşitli değişkenler bakımından incelenmesi. SDÜ Fen Edebiyat Fakültesi Sosyal Bilimler Dergisi, 31, 181-192.

Schön, D. (1987). Educating the reflective practitioner:Toward a new design for teaching and learning in the professions. San Francisco: Jossey Bass.

Schoenfeld, A. H. (1985). Metacognitive and epistemological issues in mathematical understanding. In E. A. Silver (Eds.), Teaching and learning mathematical problem solving: Multiple research perspectives (pp. 361-379). Hillsdale, Nj: Erlbaum.

Şen, H. S. (2013). Reflective thinking skills of primary school students based on problem solving ability. International Journal of Academic Research, 5(5), 41-48.

Tabachnick, B. G., \& Fidell, L. S. (2000). Using multivariate statistics. Boston: Allyn \& Bacon.

Taber, K. S. (2008). Exploring student learning from a constructivist perspective in diverse educational contexts. Journal of Turkish Science Education, 5(1), 2-21.

Taggart, G. L., \& Wilson, A. P. (2005). Promoting reflective thinking in teachers: 50 action strategies. California: Corwin Press.

Thurstone, L. L. (1931). Measurement of social attitudes. Journal of Abnormal and Social Psychology, 26(3), 249-269.

Tichenor, M., \& Plavchan, J. (2010). Summer camps: A fun way to reinforce math skills. Journal of Instructional Psychology, 37(1), 71-75.

Tok, Ş. (2008). Fen bilgisi dersinde yansıtıcı düşünme etkinliklerinin öğrencilerin akademik başarılarına ve fen bilgisi dersine yönelik tutumlarına etkisi. Illköğretim Online, 7(3), 557-568.

Uygun, K., \& Çetin, T. (2014). Sosyal bilgiler öğretiminde yansıtıcı düşünme uygulamalarının akademik başarı ve tutuma etkisi. Researcher: Social Science Studies, 2(3), 50-72.

Walker, S. E. (2006). Journal writing as a teaching technique to promote reflection. Journal of Athletic Training, 42(2), $216-221$.

Wilson J., \& Jan W. L. (1993). Thinking for themselves developing strategies for reflective learning. Australia: Eleanor Curtain Publishing.

\section{Ekler}

\section{Ek 1. Öğrenme günlüğü}


Ek 2. İki kolonlu öğrenme yazılı çalışma kağıdı örneği

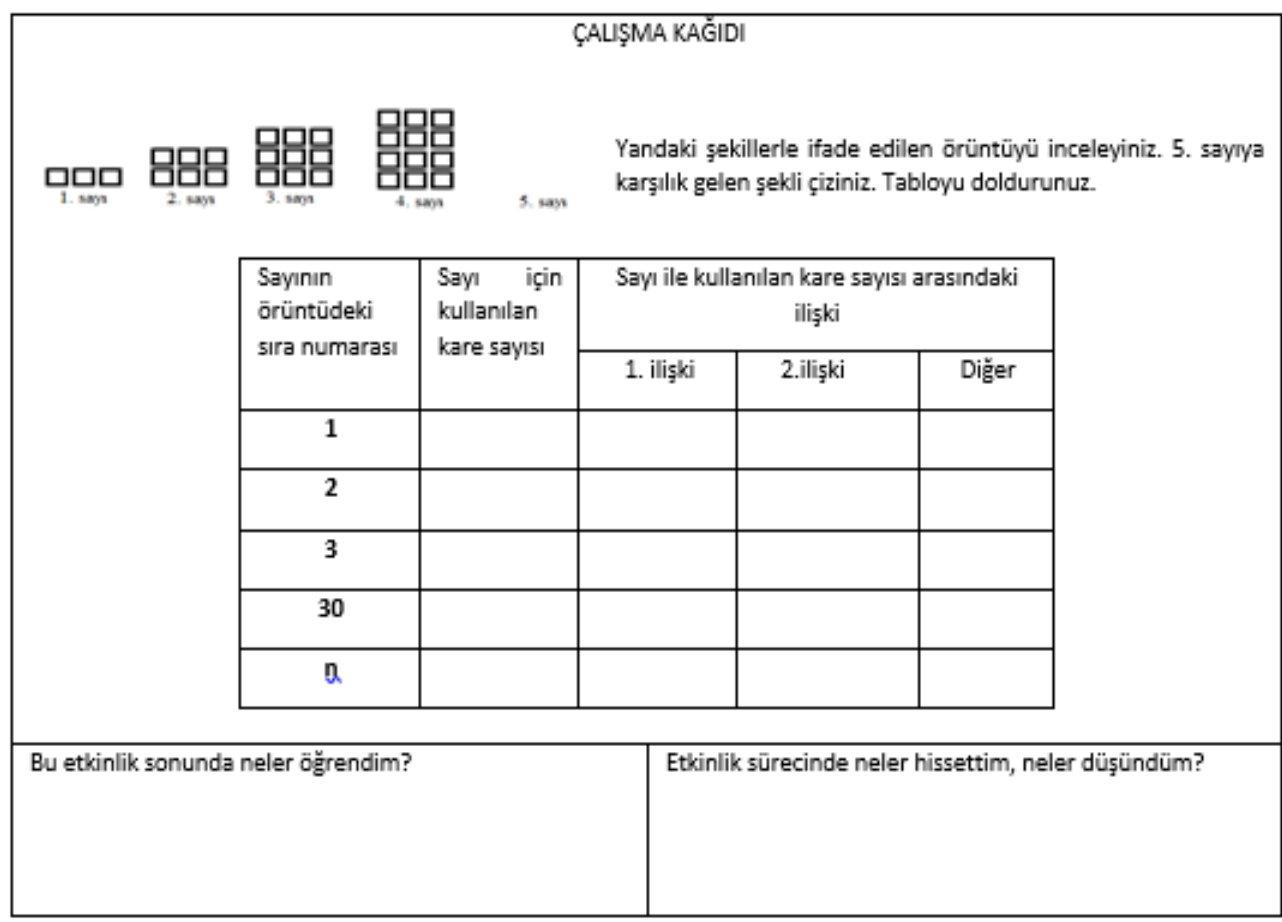

\section{Ek 3. Yansıtıcı diyalog formu}

YANSITICI DIYALOG FORMU
$>\quad$ Bu etkinliğin amaçlarını nasıl tamamladın?
$>\quad$ Bu etkinlikte başarılı olduğun durumları listeler misin?
$>\quad$ Bu etkinliği gerçekleştirirken güçlük yaşadığın durumları listeler misin?
$>\quad$ Bu etkinliği tamamlamanda sana neler yardımcı oldu?
$>\quad$ Bu etkinlikte daha iyi performans göstermen için sana neler yardımcı olabilirdi?

\section{Ek 4. Hata değerlendirme formu}

\section{Ek 5. Yönlendirme kart}

HATALARIMI DEĞERLENDIRIYORUM
$>\quad$ Vanlış yaptı̆ım adım var mı?
$>\quad$ Niçin yanlış yaptım?
Buna benzer sorularda hata yapmamak için ne yapmalıyım?
Hatalarımı düzeltmemde arkadaşımın katkıları neler?
Çalışmanın sonunda arkadaşıma tavsiyelerim:

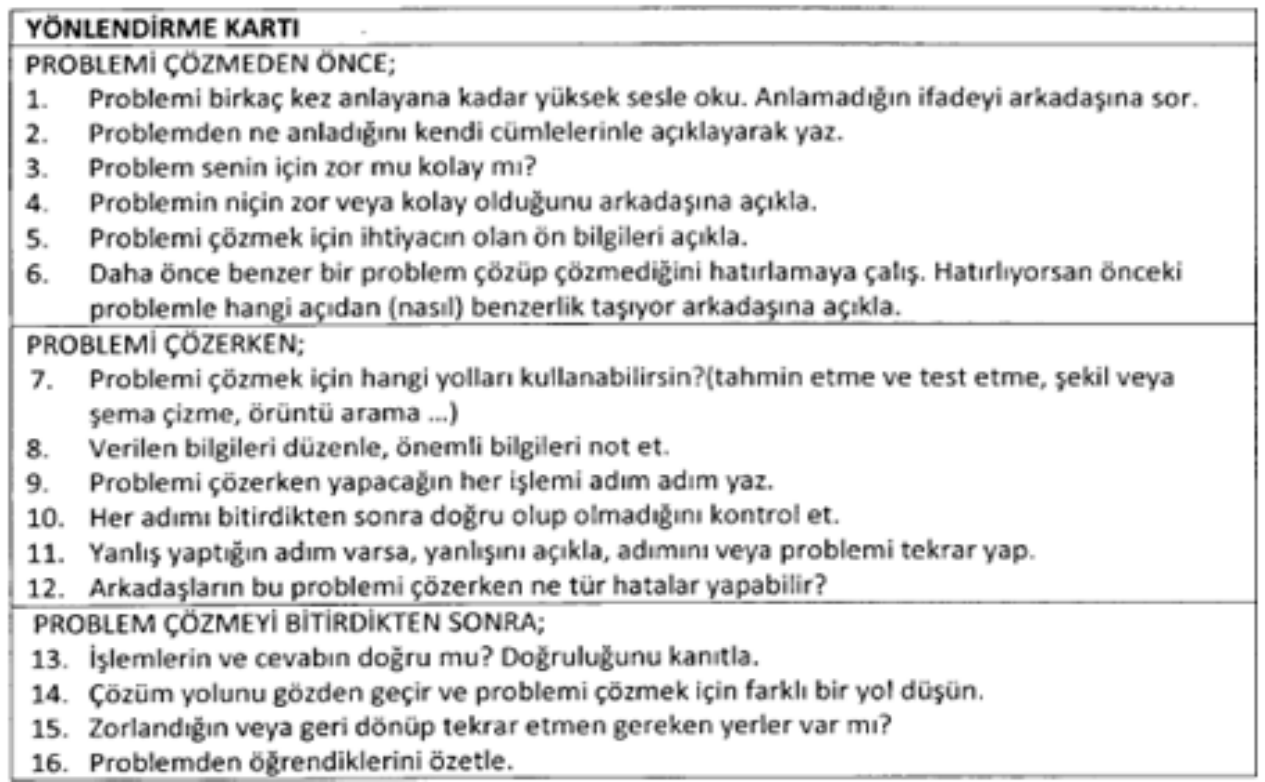

